\title{
Sound Moral Values and Development of Right Attitudes as a Panacea to Examination Malpractice in Nigeria
}

\author{
Emperor Kpangban*, O. P.Ajaja** and Sylvester E. Umudhe \\ Department of Science Education, Delta State University, Abraka, Nigeria \\ E-mail:*<emkpangban@yahoo.com>,**<osawaruajaja@yahoo.com
}

KEYWORDS Tertiary; students; perceive; effects; causes; incidence

\begin{abstract}
The major purpose of this study was to find out the students perceived causes, effects and remedies to examination malpractice in the tertiary institutions in Delta State, Nigeria by applying the principles of sound moral values and development of right attitudes. To guide this study, five research questions were raised and answered. The instruments used include; one student questionnaire and an administrative staff questionnaire. The sample of study consists of 350 students drawn from 3 campuses of the State University, three State owned Colleges of Education and three State owned Polytechnics and 7 administrative staffs drawn from the institutions from where the students were sampled. The following are the major findings of the study: (i) the incidence of examination malpractices increased in all the institutions over years, (ii) students identified 8 main causes of examination malpractices with crave for paper qualification top in the list, (iii) students identified five main effects of examination malpractices with all the students agreeing that inability to defend certificates and reduction in quality and standard of education as the most serious ones; (iv) students recommended 8 remedies to examination malpractices and of the 8,7 were hinged on the teachers calling them to be alive to their responsibilities, and (v) all the institutions studied have robust measures aimed at reducing the incidence of examination malpractices. It is mainly concluded that the incidence of examination malpractices in all the institutions is on the increase because of the ineffectiveness of the measures put in place and so the adoption of sound moral values in tackling the problem is therefore advocated.
\end{abstract}

\section{INTRODUCTION}

Today in Nigeria "examination malpractice" is a household word, and virtually everybody, knowingly or unknowingly, seems to be involved in it. Examination malpractice could be said to be an action or inaction by students, teachers, school heads, examination invigilators/supervisors and officials of examination bodies that leads to a student having an unmerited result. Examination malpractice is one of the features of a society that nurtures cheats and mediocre and turns them into celebrities. Jibril (1991) in his contribution on incidence of examination malpractice in our society, noted that it is a reflection of the moral decadence of our country.

Examination malpractice is as old as the western education itself and takes many forms in manifestation. There is hardly any examination where no form of malpractice occurs. This is true for all examinations world wide. What make the differences is the prevalence, scale, magni-

Correspondence address:

Dr. Emperor Kpangban

Department Science Education, Delta State University

Abraka Nigeria; Telephone: 0803784815

E-mail: emkpangban@yahoo.com tude and dimension. In Nigeria, the scale and dimensions have taken a frightening look that the quality of our certificates is now questioned both locally and internationally. The issue of examination malpractice is a big scandal in Nigeria. Although a lot of efforts are being made both by government, institutions, organizations and even individuals, the war is far from being won.

The history of examination malpractice in Nigeria is not recent. It dates back to the colonial era. The first examination malpractice in Nigeria was reported in 1914; when there was a leakage of question paper in the Senior Cambridge Examination. Since then, the incidence of examination malpractice has been on the increase and yearly reported. The conspicuous years reported include; 1963, 1967, 1970, 1973, 1977, 1979, 1981, 1985, 1987, 1991, 1994, 1995, 1996, 1997, 1998, 1999, 2000, 2001, 2002, 2003 (Olaope, 1997; West African Examination Council, 2004; Alutu and Aluede, 2006 and FAQ, 2006). The registrar of JAMB, Professor Bello Saliu (2002) stated that thirty-one out of one hundred and sixty-six examination towns were involved in cheating and malpractice while forty-five thousand four hundred and forty-eight candi- 
dates seeking university admission had their results cancelled in year 2002 because of examination malpractice.

The forms, means and strategies employed in carrying examination malpractices are varied and numerous. Eze and Ezeani (1991); Dare (1994); Wollherm (1996), and West African Examination Council (2005) identified the following: (i) candidates bringing books or cribs into the examination hall; (ii) insulting or assaulting any supervisor or invigilator; (iii) replacing their answer scripts with another one during or after the examination; (iv) swooping of scripts in an examination hall; and (v) impersonation as the major strategies employed in examination malpractice. Students are known to be very desperate and can do anything to achieve their objective of cheating.

The battle against examination malpractice in Nigeria is far from being won because of the caliber of people involved. Studies by FAQ (2006); and Alutu and Aluede (2006) indicated that; students, parents/guardians, schools' management and their staff, ministry officers, and examination officers are all involved in examination malpractice. At the secondary level, parent provide the resources, school heads create the enabling environment, teachers do the solving and assist in creating enabling environment, ministry officers and examination body officers cover cheats and write that all is well in centres of their interest, students copy freely while supervisors collect gratifications and all forms of inducement. When results are released, almost all the students pass with fantastic grades in the subjects they entered but inwardly, they are blank and empty. It was the very poor performances noticed among students with very high scores in matriculation examination that led to the subjection of JAMB candidates to Post JAMB tests. Oye (2006) while lamenting the effects of examination malpractices on our educational system stated that the failure rate among candidates who entered university with very high University Matriculation Examination (UME) scores is very disturbing. He found that candidates who scored more than 280 points in the UME scored less than $25 \%$ in the Post UME test. Parents are known to buy question papers for their children, write for their children and negotiate with agents of malpractice on behalf of their children.

A lot of factors both real and imagined have been isolated as the causes of examination malpractice. Aina (1991); Aliyi et al (1991); Eze and Ezeani (1991), and Denga (1993) all agreed that the central factor responsible for the hydra headed examination malpractice in the country is our orientation and the value we place on certificates. The society sees certificates as means for good job which will eventually give good life. To this end, parents, relations and even school head and their teachers tend to push their wards and students too hard to get the certificates at all cost. Other factors identified include: lack of proper teaching of students before examination, poor state of infrastructure in schools, long period of closure of schools occasioned by protracted strikes by teachers, poor admission and promotion policy by schools, inadequate staffing of schools, poor attitude of students towards their studies resulting in non-preparation for examination and a host of others.

The damage examination malpractice has done and is still doing to our educational system is better imagined than told. The most painful of all the damages is the very poor rating of our educational system in the League of Nations. It has eroded the confidence the local society and international community have in our educational system. This has culminated in subjecting Nigerian graduates seeking admission for post graduate studies in some countries to written qualifying examination before admission.

This monster must be fought with all weapons at our disposal to restore the dignity of our educational system and certificates. It is only when this battle is fought and won that our education can be for enlightenment, self reliance and restoration of the dignity of man. The purpose of this study therefore is using the tertiary institutions in Delta State, Nigeria, to find out the incidence of examination malpractice, what students say are the causes, effects, and remedies, and measures put in place by school authorities to reduce the incidence of examination malpractice. This study will also suggest how to use sound moral values and the development of right attitude to curb the menace of examination malpractices in our educational institutions.

\section{Problem of the Study}

This study emanated from the noticed huge loses incurred annually by schools, parents, government, examination bodies and students as a result of examination malpractices. Hundreds 
of thousands of students' results are either withheld, or cancelled annually in public examination. Many innocent students are punished unjustly in the event of mass cancellation of results as a result of mass cheating. Many students become frustrated in life. At the tertiary level, many students are rusticated for a good number of years and quite a reasonable number expelled from school as a result of examination malpractices.

The damage it has done to our education system is grave and thus calls for urgent steps to redress the situation. The situation calls for going to the root cause of the problem before the remedy can be found. The option left is to find out the students perceived causes, effects and remedies of examination malpractice in Nigeria. The statement of the problem therefore is; will the analyses of students' perceived causes, effects and remedies provide better strategies on how to eradicate examination malpractices in educational institutions?

\section{Research Questions}

To guide and focus this study, the following research questions were raised.

1. What is the incidence of examination malpractice among students in tertiary institutions in Delta State?

2. What do students perceive are the causes of examination malpractice?

3. What do students perceive are the effects of examination malpractices?

4. What do students perceive are the remedies to examination malpractices?

5. What measures do school authorities put in place to discourage examination malpractices?

\section{METHODOLOGY}

The design of the study is descriptive survey. Survey was used for the study because questionnaires were employed in the collection of data. Any study where questionnaire is used, the design is described as survey.

The sample of study consist of 357 subjects drawn from 3 campuses of the state university, three colleges of education, and three state owned polytechnics in Delta State, Nigeria. The subjects include of 350 students; randomly drawn from the institutions and 7 secretaries of examination disciplinary committee drawn from all the institutions.
Two instruments were used for the study; students' questionnaire on examination malpractice in our institution and examination disciplinary committee secretary questionnaire on examination malpractice in our institution. The students questionnaire consist of 42 items in three sections, scored on four point likert scale of strongly agree (SA), Agree (A), Disagree (D) and strongly disagree (SA). The examination disciplinary committee secretary questionnaire consists of 10 items - asking for declarative statements.

The content validities of the instruments were determined by giving the two instruments to two lectures in test and measurement department for their comments. This is in line with the recommendation of Wiseman (1999). Only the reliability of the students' questionnaire was determined since the examination disciplinary committee secretary questionnaire asked categorical questions. The reliability of students' questionnaire was done using Cronbach's coefficient alpha approach. Wiseman (1999) recommended that it is the appropriate approach for determining reliabilities of tests whose answers are not just one. The calculated Alpha value for the questionnaire was 0.79 which is adjudged as being reliable. The objectivity of the instrument was determined by using interrater reliability. This was again done to be in line with the recommendations of Thorndike and Hagen (1977), and Wiseman (1999). They recommended that the pooling of the ratings of several judges about an individual will produce a composite that is more reliable. Using Pearson product moment correlation, to compare the ratings of two judges, an $r=0.82$ was obtained showing the instrument is very objective and so was used. The responses of the respondents were arranged in tables as shown below to answer the raised questions.

\section{RESULTS}

Shown in Table 1, the incidence of examination malpractice increase over the years in all the institution under study. The number of reported cases of examination malpractice in all tertiary institutions in Delta State, Nigeria followed this order; 2002/03 (737), 2003/04 (1060), 2004/05 (1656) and 2005/06 (1690).

Shown in figure 1 , the regression graph on incidence of examination malpractice in the 
Table 1: Incidence of examination malpractice in tertiary institutions in Delta State 2003 - 2006 Academic Sessions

\begin{tabular}{lrrrr}
\hline $\begin{array}{l}\text { Named of } \\
\text { institutions }\end{array}$ & \multicolumn{4}{c}{$\begin{array}{c}\text { Reported cases of } \\
\text { exam malpractice }\end{array}$} \\
\cline { 2 - 5 } & $\begin{array}{r}2002 / 03 \\
\text { Session }\end{array}$ & $\begin{array}{r}\text { 2003/04 } \\
\text { Session }\end{array}$ & $\begin{array}{r}\text { 2004/05 } \\
\text { Session }\end{array}$ & Session \\
\hline All the & $\begin{array}{r}737 \\
\text { Institutions together }\end{array}$ & 1060 & 1656 & 1696 \\
\hline
\end{tabular}

Source: Secretaries of Examination Disciplinary Committees.

tertiary institutions, indicates that the number of students involved in examination malpractice increased over the years.

On students perceived causes of examination malpractices, shown in table 2 , the students, identified eight major causes of examination malpractices. The most highly rated among the major causes of examination malpractice is "The crave for paper qualifications" where $92 \%$ of the respondents agreed that it is the main cause of examination malpractice in schools. Poor teaching by teachers was also rated as the second most important reason why students engage in examination malpractices. The students also placed on third position the corrupt disposition of teachers and other exam officers

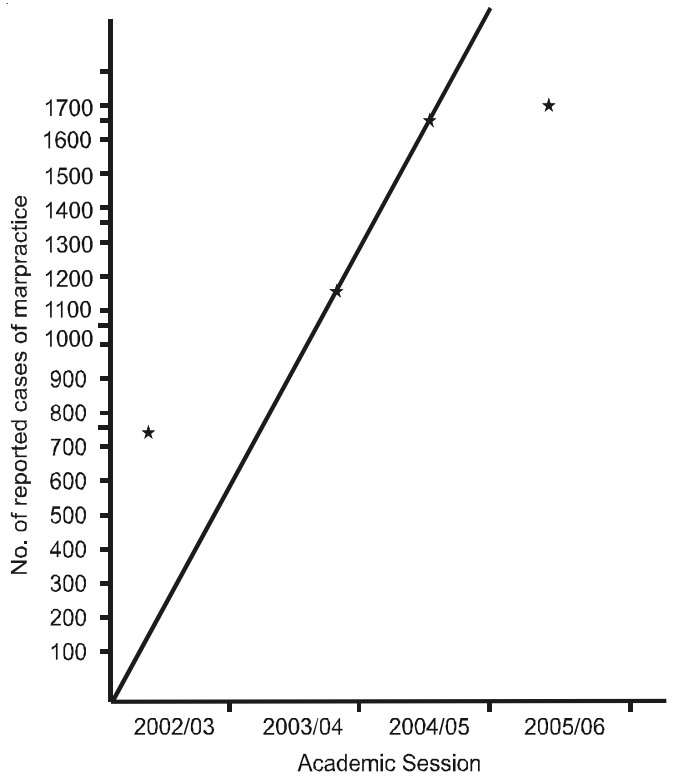

Fig.1. Regression graph showing the trend in incidence of examination malpractice in tertiary institutions. as another important reason why they engaged in examination malpractices.

On students perceived effects of examination malpractices, the students identified five major effects as shown in table 3 . The respondents found; inability to defend certificates, reduction in quality and standard of education, decrease in national productivity, employers lose of confidence in nation's educational system and wastage of resources and time, as those students who cheated at lower levels of education are unable to cope at higher levels as the major effects of examination malpractice. All the respondents rated the inability to defend certificate and reduction in quality and standard of education in a country as the most serious effects of examination malpractice.

Shown in Table 4, the students isolated eight major remedies to significantly reduce the incidence of examination malpractices in our institutions of learning. All the students recommended good teaching and very positive work habit by teachers, thorough and transparent invigilation and supervision of examination, and teachers' exhibition of honesty, rejection of vices like bribery, cheating and corruption in what ever form as the most significant steps to be adopted if examination malpractice is to be curbed. A thorough study of the recommendations shows that the solution to the problems of examination malpractice can mainly be found through the teachers' change in disposition.

On measures taken by institutions to reduce the incidence of examination malpractices, the following measures are identified as shown in Table 5:

i) Appointment of supervisors and invigilators to conduct examinations and reports all incidence of examination malpractice to the appropriate committees.

ii) Setting up examination monitoring committees to oversee the conduct of examination in the various institutions.

iii) Setting up examination disciplinary committees to try examination offenders and recommend appropriate punishment to school authorities.

iv) Setting up of counselling units to advice students having problems with their studies and the need to stay away from examination malpractices.

Table 6 shows the summary of recommendations by Delta State University and College of Education Agbor examination disciplinary 
Table 2: Students' Perceived major causes of examination malpractices in our institutions

\begin{tabular}{|c|c|c|}
\hline $\begin{array}{l}\text { S. Item Description } \\
\text { No. }\end{array}$ & $\begin{array}{l}\text { No. of } \\
\text { respon- } \\
\text { dents }\end{array}$ & $\%$ \\
\hline 1. The crave for paper qualifications & 322 & 92 \\
\hline 3. Poor teaching on the part of teachers & 298 & 85 \\
\hline 15. Easy inducement of exam officers and teachers with any form of gratification. & 291 & 83 \\
\hline $\begin{array}{l}\text { 2. Deviant behaviours among students like cultism, riot, arm robbery, unnecessary } \\
\text { socialization, and prostitution which prevent students from attending lecturers and } \\
\text { participating in other classroom activities. }\end{array}$ & 280 & 80 \\
\hline 7. Rising cost of education that propels academically weak students to want to pass at all cost. & 273 & 78 \\
\hline 6. Poor conduct of examinations by invigilators and supervisors. & 245 & 70 \\
\hline $\begin{array}{l}\text { 12. Parents buying of question papers for children, hiring syndicates to write for children, } \\
\text { inducement of lecturers to favour their children. }\end{array}$ & 238 & 68 \\
\hline $\begin{array}{l}\text { 11. Threat by government and school management to use performance of students in } \\
\text { examinations to determine school benefits and promotion of teachers. }\end{array}$ & 235 & 67 \\
\hline
\end{tabular}

Table 3: Students' perceived major effects of examination malpractices in our institutions

\begin{tabular}{|c|c|c|}
\hline $\begin{array}{l}\text { S. Item Description } \\
\text { No. }\end{array}$ & $\begin{array}{l}\text { No. of } \\
\text { respon- } \\
\text { dents }\end{array}$ & $\%$ \\
\hline 1. Examination cheats obtain certificates which they cannot defend. & 350 & 100 \\
\hline 2. Examination malpractice has reduced the quality and standard of education in the country. & 350 & 100 \\
\hline $\begin{array}{l}\text { 8. Examination malpractice adversely affects national productivity as the certificates workers } \\
\text { possess are not backed with commensurate knowledge, skills and values }\end{array}$ & 336 & 96 \\
\hline $\begin{array}{l}\text { 5. Examination malpractice makes employers of labour lose confidence in the educational } \\
\text { system and the credentials that are paraded by job seekers. }\end{array}$ & 333 & 95 \\
\hline $\begin{array}{l}\text { 6. Examination malpractice leads to high educational wastage as those who cheat to pass } \\
\text { examinations at a lower level, achieve very poorly at a higher level. }\end{array}$ & 312 & 89 \\
\hline
\end{tabular}

Table 4: Students' perceived remedies to examination malpractices

\begin{tabular}{|c|c|c|}
\hline $\begin{array}{l}\text { S. Item Description } \\
\text { No. }\end{array}$ & $\begin{array}{l}\text { No. of } \\
\text { respon- } \\
\text { dents }\end{array}$ & $\%$ \\
\hline 1. Examination cheats obtain certificates which they cannot defend. & 350 & 100 \\
\hline 2. Examination malpractice has reduced the quality and standard of education in the country. & 350 & 100 \\
\hline $\begin{array}{l}\text { 8. Examination malpractice adversely affects national productivity as the certificates workers } \\
\text { possess are not backed with commensurate knowledge, skills and values }\end{array}$ & 336 & 96 \\
\hline $\begin{array}{l}\text { 5. Examination malpractice makes employers of labour lose confidence in the educational } \\
\text { system and the credentials that are paraded by job seekers. }\end{array}$ & 333 & 95 \\
\hline $\begin{array}{l}\text { 6. Examination malpractice leads to high educational wastage as those who cheat to pass } \\
\text { examinations at a lower level, achieve very poorly at a higher level. }\end{array}$ & 312 & 89 \\
\hline $\begin{array}{l}\text { 9. Teachers should exhibit good teaching and very positive work habit that emphasizes } \\
\text { excellent achievement through hard work }\end{array}$ & 350 & 100 \\
\hline 1. Thorough and transparent invigilation and supervision of examination by all concerned. & 350 & 100 \\
\hline $\begin{array}{l}\text { 10. Teachers must emphasize honesty and good character and reject vices like bribery, } \\
\text { cheating and corruption. }\end{array}$ & 350 & 100 \\
\hline $\begin{array}{l}\text { 4. Perpetrators of examination malpractice should be strictly dealt with using the } \\
\text { examination laws of the institution. }\end{array}$ & 305 & 87 \\
\hline $\begin{array}{l}\text { 12. Teachers found guilty of perpetrating examination malpractice should have their licenses } \\
\text { withdrawn by Teachers' Registration Council of Nigeria and prosecuted in a court of law. }\end{array}$ & 298 & 85 \\
\hline $\begin{array}{l}\text { 8. Government should d-emphasize paper qualification for employment, and in its places } \\
\text { emphasize demonstration of skills required for job performance and the necessary attitude. }\end{array}$ & 280 & 80 \\
\hline $\begin{array}{l}\text { 15. Teachers and school heads should display in their work sound moral values of equality, honesty, } \\
\text { honour, respect, self-control, responsibility, social justice, respect for authority and so on. }\end{array}$ & 263 & 73 \\
\hline 2. During every examination, the ratio of examinees to invigilators should not exceed $50: 1$ & 245 & 70 \\
\hline
\end{tabular}

committees on examination malpractice for 2005/ 06 session. The table indicates that in science education department of Delta State University, 22 students were tried, 4 discharged, 3 warned, 9 rusticated and 6 expelled. In the College of
Education Agbor 150 were tried, 70 rusticated, 69 suspended indefinitely for not appearing and 11 expelled. Table 6 was included to illustrated efforts made in real terms to curb examination malpractices in institutions of learning. 
Table 5: Measures taken by institutions to reduce examination malpractices S. Name of Institution Measures Power and responsibilities No.

1. Delta State i) Posting of supervisors and Report cases of exam malpractices to
University, Abraka invigilators to exam halls university monitoring team.

ii) Faculty monitoring team. Report cases of exam malpractices to university monitoring team.

iii) University monitoring team Report all cases of exam malpractices to the

iv) Examination disciplinary committee University examination disciplinary committee. v) University counseling unit.

2. Colleges of Education i) Posting of supervisors and invigilators to exam halls under strict instructions

ii) Examination monitory team

iii) Disciplinary Committee

3. State Polytechnics i) Lecturers and seminar on exam malpractice.

ii) Warning of supervisors and invigilators to be strict on conduct of exam

iii) Anti-exam malpractice team

iv) School disciplinary committee.
Try's offending students and recommend appropriate punishments for those found guilty to the VC.

To counsel students on their study problems and the need to stay away from examination malpractices. Report cases of examination malpractices to disciplinary committee.

Report cases of examination malpractices to disciplinary committee.

To try exam cheats and make appropriate recommend-dations to college authority To sensitize fresh students on dangers of examination malpractice.

Report cases of examination malpractices to disciplinary committee.

Monitors conduct of exams and reports incidence of exam malpractice to school disciplinary committee. Tries all cases of exam malpractice and make recommendations to management for ratification

Table 6: Summary of recommendations by Delta State University Abraka and college of education Agbor examination disciplinary committee on examination malpractices of 2005/2006 session

\begin{tabular}{|c|c|c|c|c|c|c|c|}
\hline \multirow{2}{*}{$\begin{array}{l}\text { S. } \\
\text { No. }\end{array}$} & \multirow[t]{2}{*}{ Department/Institution } & \multirow{2}{*}{$\begin{array}{l}\text { No. } \\
\text { tried }\end{array}$} & \multicolumn{5}{|c|}{ Penalty } \\
\hline & & & Discharged & Warned & Rusticated & Indefinite Suspension & Expelled \\
\hline 1 & $\begin{array}{l}\text { Extract for Science } \\
\text { Education Department } \\
\text { DELSU Abraka }\end{array}$ & 22 & 4 & 3 & 9 & - & 6 \\
\hline 2 & College of Education Agbor & 150 & - & - & 70 & 69 & 11 \\
\hline
\end{tabular}

Source: Institution Students Affairs Department

\section{DISCUSSION}

This study has been able to expose the major causes, effects and remedies to examination malpractices using the ideas of the main actor the student. This study moved a little further from what most researcher have done in the past by collating most of their data from the school authorities and members of the larger society. Most of the data and information on causes and remedies can be adduced to be mainly impressionistic ideas of people who are not the main actors of examination malpractice. Any solution to examination malpractice devoid of the major actors' (the students) input will always fail. They know why they engage in examination malpractices and thus stand in a better position to proffer remedies to curb it.
One of the findings of this study indicates that the incidence of examination malpractices in our institutions of learning is increasing every year. This goes to prove that the various measures put in place to fight the monster have not been effective. The students not being involved in finding solutions to examination malpractices may be the reason.

The students through their responses stated that the most significant causes of examination malpractices is the desire to acquire certificate which is the only and main condition for getting access to more respectable jobs in Nigerian society. This therefore lures students to attempt to pass their examinations through any means no matter the cost. This finding agrees with the findings of Iheanacho (1997), Maduka (2001), McCabe (2001), Alutu and Alutu (2003), and FAQ 
(2006). Whitley (1998), and Olaewe (2003) stated that most students are involved in examination malpractices because of fear of failure and expectations of success.

Also fingered as a second most important cause why students cheat in examination is poor teaching on the part of teachers. Most students complain that a lot of their teachers do not come regularly to teach them. Some, who come, teach so badly that a greater percentage of the class does not internalize anything. Those categories of students who are either not taught at all or are very poorly taught are prone to examination malpractices. If these students are to write a centrally set examination with other students who have been well taught, for them to pass, the only way out is to cheat.

All the students generally responded that examination malpractices are undesirable and have far reaching consequences for the student as an individual and the society at large. Among the major effects of examination they isolated, all agreed that the inability to defend certificates and the reduction of the quality and standard of education in the country are the most serious ones in ranking. This finding agrees with the position of Oye (2006) who lamented the very poor performance of students who score 280 points and above in UME and in Post JAMB tests.

The bulk of the recommendations by students on how to curb or significantly reduce the incidence of examination malpractices are thrown back on the teachers - and the school. Their suggestions tend to indicate that the arrow heads in examination malpractices are the schools and the teachers. In other words if they say no to examination malpractice the incidence will vanish in our institutions. Most schools and teachers nurture examination malpractices and perpetuate it in the institutions through their actions and deeds. Teachers poorly prepared both in training and morals cannot give better than what is in them. This agrees with the statement in the National Policy on Education that "the quality of education of any nation cannot rise above the quality of her teachers" (Federal Republic of Nigeria, 2004). This also agrees with the caution by Ajaja and Kpangban (2005) on the need to strengthen teacher education programmes because of the noticed poor performances of teachers in the field.

A look at the various measures put in place by the various institutions to curb examination malpractices indicate very robust and well thought-out strategies. As robust and novel as the strategies are the war on examination malpractice is still far from being won. This therefore raises a fundamental notion that perhaps the right strategy to adopt in fighting examination malpractice in our society has not been found. A major finding of this study based on the students' responses threw the major challenge of finding solutions to examination malpractices in institutions of learning to the school and teachers. It is our view that the task of curbing examination malpractices using students' suggestions can be achieved by the school and its teachers through the adoption sound moral values and the development of right attitudes. This will be discussed under recommendations.

\section{CONCLUSION}

Based on the findings of this study, the following conclusions were drawn:

The first among them is that among the institutions studied, the incidence of examination is on the increase annually. This indicates that the measures put in place to combat examination malpractices are unable to address the issue.

The second in the list is that the causes of examination malpractices are numerous but top on the list are, crave for paper qualification and poor teaching by teachers.

Thirdly, examination malpractice is undesirable in all aspects since it mainly reduces the value of certificates and rubbishes the quality and standard of education in any country.

Fourthly, it is the school and its teacher's disposition that make examination malpractice to thrive in our institution. It is therefore only the school and its teachers that can completely eradicate examination malpractices.

Finally, since the very robust measures put in place have failed to reduce the incidence of examination malpractices in our institutions, it is advocated that sound moral values and development of right attitudes approach be adopted.

\section{RECOMMENDATIONS}

Since the measures put in place by the various institutions does not seem to be winning the war against the scourge of examination 
malpractices in the country, and the fact that most of the recommended strategies by students are hinged on the shoulders of the school and its teachers it is our conviction that the adoption of sound moral values and the development of right attitudes in the business of school and schooling might make the difference. To this end, the following recommendations are made:

1. Teachers should cultivate the attitude that teaching is the best profession in the world and that you can contribute your quota to the development of society best through teaching.

2. Tell yourself that it is only through your treating teaching with the seriousness and importance it deserves can the schools perform their society-ascribed roles one of which is acting as a screening device in selecting the most able for the best jobs. This last role is anchored on an efficient, effective and fair evaluation system, managed with integrity.

3. Counsel students to have faith in their own ability - that they should assure themselves that if other students can pass their examinations genuinely, so can they.

4. Teachers should help students form the attitude that nothing good comes easy-that they have to form positive study habits to succeed in schools: (a) budgeting one's time for private study among the subjects, cocurricular activities, afternoon rest/siesta and a sound night sleep; (b) reading and testing oneself alongside; (c) forming study groups and discussing different difficult concepts; and (d) cultivating a desire to improve upon previous performances.

5. Teachers need to acquire and display sound moral values of integrity and moral probity in order to resist stoutly their students wanting to bribe them so that they can aid them in cheating during examination. These moral values will also help them to rebuff parents/ guardians wanting to influence them to inflate their children's continuous assessment scores.

6. Teachers need to imbibe and display the right attitude of hard work and creativity and inculcate same in their students by giving regular assignments, projects, laboratory and workshop practical, which are promptly corrected and returned in a guidanceoriented manner. Teachers should teach to make their students learn.
7. Teachers, Vice Principals and Principals also need to acquire and display in their work in school sound moral values of equality, honesty, honour, respect, self-control, responsibility, social justice, respect for authority, and so on.

\section{ACKNOWLEDGEMENT}

We are sincerely grateful to all our respondents for the very useful information they gave which helped us in the conduct of this study. We are indeed very grateful to all the executives of Students Affaires and secretaries of disciplinary committees in all the institutions of our study for their assistance. We are especially grateful to Mr. Jacob Okobia of College of Education, Agbor for his interest in the work and the speed with which he gave all the information we needed. To our research assistant, Ejire Eravwoke and Mike who typed the work at a very short noticed we will forever remain grateful.

\section{NOTES}

Trend: This means the pattern of occurrence over time.

Incidence: This means the frequency of occurrence of examination malpractices in institutions of learning.

UME: This means university matriculation

examination

JAMB: This is described as Joint Admission and Matriculation Board

Post JAMB This is the test administered by universities Test: $\quad$ to students who passed UME before they are admitted to the universities.

Tertiary These include; universities, colleges Institutions: of education and polytechnics.

DELSU: This is Delta State University.

V.C.: $\quad$ Vice Chancellor

\section{REFERENCES}

Aina, O. 1991. "In Advocates of examination malpractice." <www.albaspectrum. com/articles> accessed 23 June, 2007.

Ajaja, O.P. and E. Kpangban. 2005. "Declining Performance of Science Teachers: A case of poor training in teacher education programmes." Nigerian Journal of Teacher Education and Teaching, 1(1): 22-28.

Aliyu, et al. 1991. "In Advocates of examination malpractice." <www.albaspectrum.com/articles> accessed 23 June, 2007.

Alutu, A.N.G. and O. Aluede. 2006. Secondary schools student's perception of examination malpractice and examination ethics. J. Hum. Ecol., 20(4): 295300 . 
Alutu, O.E and A. N. G. Alutu. 2003. "Examination malpractice among undergraduates in a Nigerian University: Implications for academic advising." Guidance and Counselling, 18: 149-152.

Dare, M. 1994. "In Advocates of examination malpractice." <www.albaspectrum. com/articles> Accessed 23 June, 2007.

Denga, D. L. 1993. "In Advocates of examination malpractice." <www.albaspectrum.com/articles> Accessed 23 June, 2007.

Ese, T.I. 1991. "In Advocates of examination malpractice." <www.albaspectrum. com/articles> Accessed 23 June, 2007.

Eze, T.I. and P. M. Ezeani. 1991. "Examination malpractice: implications for teacher education." Proceedings of the National Conference of the NCE Teacher Educators in Nigeria.

FAQ 2006. "Advocates of examination malpractice." <www.albaspectrum.com/ articles> Accessed 23 June, 2007.

Federal Republic of Nigeria 2004. National Policy on Education. Lagos: Federal Ministry of Information.

Iheanacho, H. 1997. "Social and Economic Dimensions of examination malpractice in Nigeria." The Calabar Counsellor, 1: 32-37.

Jibril, M. 1991. "Examination malpractice in Niegria." In Newswatch Magazine of July, Edition. Lagos: Newswatch Publishers 9-15.
McCabe, D 2001. "Students cheating in American high school." <www.Academicintegrity.org> Accessed 30 March, 2006

Oladope, O. 1997. "In Advocate of examination malpractice." <www.albaspectrum. com/articles> Accessed 23 June, 2007.

Olaewe, O.O. 2003. Test and Measurement in Education: An Illustrative Approach. Iwo: Agboda Publishing Ltd.

Oye, I. 2006. "Quality education standards: Need for a refined university admission process." Paper presented at the $6^{\text {th }}$ NAPEUAP Leadership forum in Calabar.

Salim, B. 2002. "In Advocates of examination malpractice." <www.albaspectrum. com/articles> Accessed 23 June, 2007

Thorndike, R.L. and E. P. Hagen. 1977. Measurement and Evaluation. New York: John Wiley and Sons.

West African Examination Council 2004. Statistics of Incidence of Examination Malpractices. Abuja: West Africa Examination Council.

Whitley, B.E. 1998. "Factors associated with cheating among college students." A Review Research in Higher Education 39: 235-274.

Wiseman, D.C. 1999. Research Strategies for Education. London: Thomson Publishing Europe.

Wollherm, J. 1996. "In Advocates of examination malpractice." <www.albaspectrum.com/articles> Accessed 23 June, 2007. 